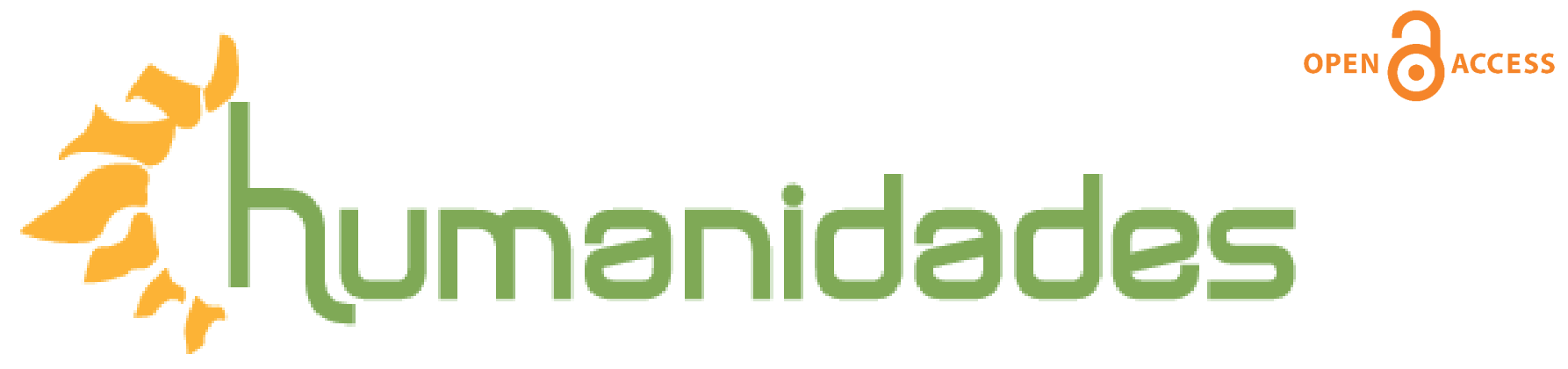

Revista de la Escuela de Estudios Generales, Universidad de Costa Rica

Enero-junio, 2018 •Volumen 8, número 1 • EISSN 2215-3934 •pp. 197-210

Recibido: 08-Noviembre-2017 Aceptado:13-Diciembre-2017

\title{
Del amor hacia el desamor: Cartas de Eunice Odio a Rodolfo
}

DOI: http://dx.doi.org/10.15517/h.v8i1.31752

\section{Licda. Tatiana Herrera A vila}

Universidad de Costa Rica, Escuela de Estudios Generales, Costa Rica.

Correo electrónico: tatiana.herrera@yahoo.es

Todos los derechos reservados. Universidad de Costa Rica. Esta revista se encuentra licenciada con Creative Commons. Reconocimiento-NoComercial-SinObraDerivada 3.0 Costa Rica. Correo electrónico: humanidades@ucr.ac.cr / Sitio web: http://revistas.ucr.ac.cr/index.php/ humanidades 


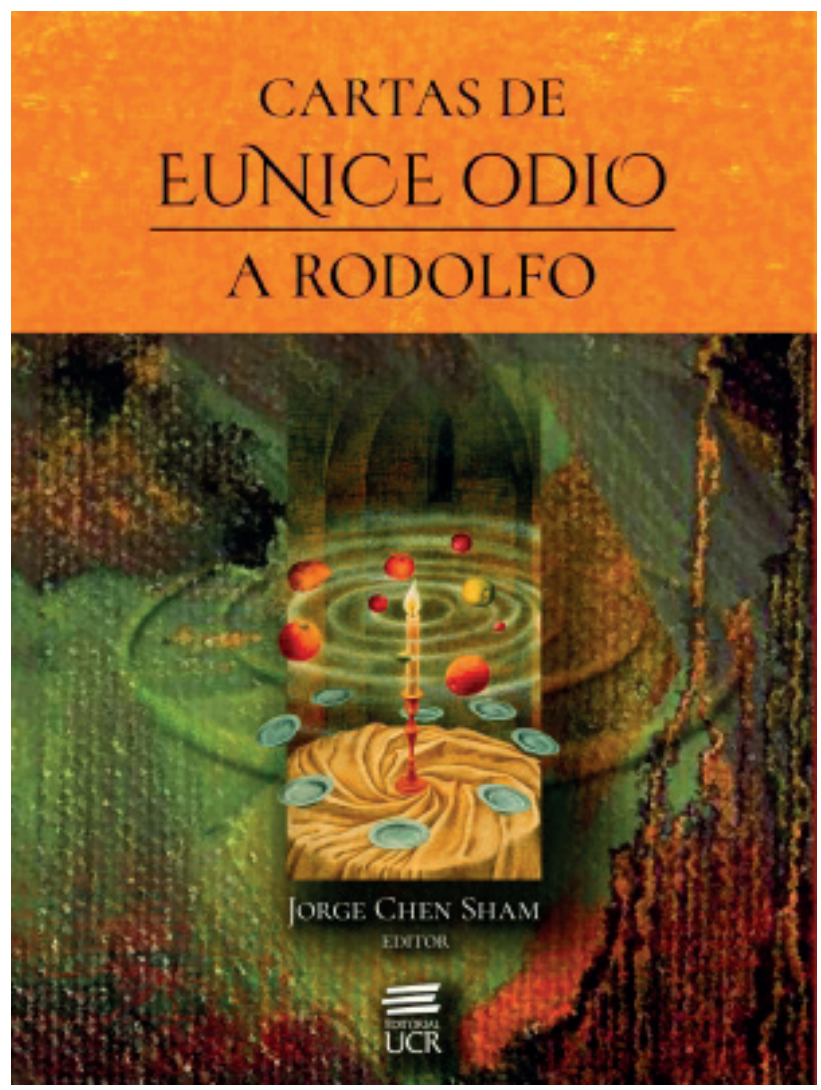

Del amor hacia el desamor: Cartas de Eunice Odio a Rodolfo Editorial de la Universidad de Costa Rica, 2017 ISBN: 978-99-6846-628-8 
Del amor hacia el desamor:...

El género epistolar constituye una de las formas literarias que data de larga trayectoria en la cultura occidental, remontándose a la Antigüedad clásica -baste mencionar las conocidas cartas de Cicerón o de Horacio-, e incluso al antiguo Egipto, con las Sebayt (III milenio a.C.) que realizaban los escribas con fines didáctico-moralizantes y cívicos y, por supuesto, no debe omitirse el epistolario bíblico. En la Edad Media y durante el Renacimiento, este género continuó su evolución, especialmente con Erasmo de Rotterdam y, para el siglo XIX, en pleno Romanticismo, alcanzó un período de esplendor, en tanto posibilitó la expresión de emociones y sentimientos, es decir, la expresividad del individuo; no es casual que la mayoría del narrador de cartas sea en primera persona. Por ello, cabe señalar que esta herramienta narrativa se ha mantenido presente a lo largo de la historia, con diversas funciones, claro está, pero independientemente de ello, siempre registrando hechos menores y mayores de la vida humana.

La misiva responde a un acto comunicativo, palpablemente, y a menudo mantiene una estructura perfilada en la retórica como ars dictaminis, con sus respectivos y consabidos salutatio, captatio benevolentiae o expressio malevolentiae, narratio, petitio y conclusio.

Por otra parte, la carta es bidimensional, debido a que comporta tanto una perspectiva privada (micro, particular, biográfica) como una visión pública (macro, sociocultural) que registra contextos, textos, paratextos, discursos e ideologías (Hintze y Zandanel, 2012).

Consciente de esto, el doctor Jorge Chen Sham -profesor catedrático de la Universidad de Costa Rica, filólogo, poeta y reconocido investigador de las literaturas españolas, centro y latinoamericanas- en su nuevo libro Las Cartas de Eunice Odio a Rodolfo (2017), se aboca a la edición de la correspondencia entre la afamada escritora costarricense Eunice Odio, quien no necesita presentación, y su compañero sentimental y esposo, Rodolfo Zanabria.

En todo caso, cabe traer a colación que Eunice Odio es una de las escritoras costarricenses más importantes y reconocidas; poeta de transición entre el realismo y el vanguardismo, muy prolífica pues empezó a publicar en 1948 tanto en Costa Rica como en México y en Argentina, y terminó en 1972, de lo que da cuenta sus obras completas editadas por la investigadora Peggy Von Maye r en la Editorial 
Costa Rica. De la cronología biográfica, los datos son vagos y difusos, su nacimiento se consigna con fechas diferentes, aunque se ha llegado al consenso de 1919, y con su muerte ocurre lo mismo, aunque se registra 1974. Aparte de destacar por su producción poética, la escritora tuvo una vida llena de pasión y polémica, de lo que se ha escrito múltiples veces.

Por su parte, no es la primera vez que don Jorge Chen se ocupa de la poeta en sus investigaciones, si no que ha dedicado varios artículos al estudio de su obra y sus paralelismos con los escritos de Yolanda Oreamuno, otra gran escritora costarricense, contemporánea de Odio. Incluso, Chen publicó, en coautoría con Rima de Vallbona, La palabra innumerable: Eunice Odio ante la crítica (2001).

De esta manera, Chen no es extranjero en el mundo poético de Odio, y en consecuencia, en este nuevo libro sobre la correspondencia entre la poeta y su esposo, logra abordar el tema con una gran propiedad.

Aquellos investigadores que toman un epistolario como objeto de estudio, generalmente coinciden en seguir un método que, de una u otra manera, cumple con cuatro diferentes pasos, tal y como lo señala el profesor de literatura Darcie Doll:

"1) empleo de la carta como fuente documental para reconstruir la biografía de un individuo; 2) como elemento auxiliar para estudiar la producción literaria de un determinado escritor o poeta; 3) consideración de la carta como factor estructural de géneros mayores; 4) como documento auxiliar de la investigación histórica, observada como conjunto de datos e informaciones que permiten reconstruir e interpretar aspectos de diferentes períodos (Doll, D. 2002).

El trabajo de don Jorge Chen no es la excepción y, con una sorprendente minuciosidad, se dedica a estas etapas, específicamente se circunscribe a las dos primeras fases y, de alguna manera, a la cuarta; posibilitándole al lector, en este orden de ideas, asistir a la reconstrucción de la biografía de Eunice Odio, de su contexto y atisbar la materia prima de muchas de sus producciones, de modo tal que la comprensión obtenida de la obra poética odiana resulta compleja e integral.

En este sentido, este libro constituye más que una simple adición al numeroso corpus crítico de la obra de la poeta costarricense y trasciende el nivel meramente 
Del amor hacia el desamor:...

informativo, o incluso el ámbito privado o privadísimo, en términos de Pedro Salinas (1993), para alcanzar el interés literario y público. Y es que ciertamente, como decíamos, analiza, decanta y pone en escena aspectos meramente biográficos y cotidianos, como dónde quedaba la residencia de la escritora y cómo era ésta, sus problemas económicos, sus afectos, sus idas al mercado o su gusto por las mariposas. Pero también, su angustia ante la página en blanco, sus miedos o sueños que luego se filtrarían en sus a veces crípticos y siempre inspirados poemas.

Es así como Chen, con su lente de filólogo experto, pero simultáneamente con el matiz de la mirada sensible del poeta, se dedica, en un primer apartado introductorio del texto, al análisis de las diferentes condiciones de posibilidad de la mencionada correspondencia entre la poeta y su compañero sentimental. Elabora una presentación de ambos: Eunice, el emisor y Rodolfo, receptor de las epístolas. Seguidamente, explica cómo se permitió la publicación de éstas; pues al investigador le fueron confiadas, en desorden, por la escritora Rima de Vallbona, quien las tenía en su poder debido a que el propio destinatario, el pintor Rodolfo Zanabria, quería darlas a conocer. Incluye, también, el estudio de las implicaciones de la consecuente transformación de documentos privados a públicos y, por lo tanto, la intromisión de lectores no previstos, así como el abordaje al discurso amoroso y su pathos.

A continuación, en una segunda parte, el editor transcribe treinta y ocho cartas de Eunice a Rodolfo, y es entonces cuando encontramos la caja de sorpresas que éstas encierran, mientras asistimos a todo el torrente de emociones de una relación que se desplaza del enamoramiento más profundo, donde el receptor es identificado como oso u osito, hacia el odio más insigne; dejando vislumbrar, asimismo, la descomunal y desenfrenada imaginación de una escritora que ha sido catalogada no pocas veces como la voz poética femenina más importante de Costa Rica, a pesar de su odio-amor a este país.

De esta manera, este original texto de Chen sorprende y provoca, ya que se perfila como un estudio filológico sí, pero que, adicionalmente, nos zambulle en una historia de amor borrascosa, romántica, llena de las imágenes propias de la poética de Eunice. Y es que se nos devela, de esta manera, ya no la escritora que todos podemos perfilar desde sus textos asombrosos, o desde toda la crítica literaria o, incluso, a la luz de los diversos testimonios que nos llegan de sus conocidos, y amigos o enemigos; sino que más bien se nos presenta a la mujer enamorada, 
a la mujer sensual, a la mujer sufrida, a la mujer amada y amante, a la olvidada y abandonada, a la elemental, la humana demasiado humana.

Después de leer Cartas de Eunice Odio a Rodolfo no queda más que decir Ecce mullier, que ama y odia como cualquiera de nosotros, o, por el contrario, como únicamente lo podía hacer la insondable Eunice.

\section{Referencias}

Chen Sham, J. (2017). Cartas de Eunice Odio a Rodolfo. San José: Editorial de la Universidad de Costa Rica.

Doll Castillo, D. (2002.) La carta privada como práctica discursiva: algunos rasgos característicos. Signos, 35 (51/52), 33-57. http://www.scielo.cl/scielo. php?script=sci_arttext\&pid=S0718-09342002005100003

Hintze, G. y Zandaniel., M. A. (2012). "Algunas nociones sobre el género epistolar a propósito de las cartas de Francisco Romero". Recuperado de http://www.scielo.org.ar/scielo.php?script=sci_arttext\&pid=S1853-31752012000200002. Cuyo (versión Online). 29 (2) Mendoza dic. 2012.

Salinas, P. (1993). "Defensa de la carta misiva y de la correspondencia epistolar". En: El defensor. Introducción de Jun Marichal. Madrid: Alianza. 19-113.

\section{¿Cómo citar este artículo?}

Herrera Ávila, T. (Enero-junio, 2018). Del amor hacia el desamor: Cartas de Eunice Odio a Rodolfo. Revista humanidades, 8(1), 206- 210 doi: http:// dx.doi.org/10.15517/h.v8i1.31752 